\title{
National and Transnational Impacts of Terror on Hotel Stock Prices
}

\author{
Dlawar M. Hadi ${ }^{1 *}$, Farman M. Ahmed² \\ ${ }^{1}$ Department of Accounting, College of Business, Komar University of Science and Technology, Sulaymania, Kurdistan Region, Iraq, \\ ${ }^{2}$ Department of Banking and Finance, College of Business Economy, Eastern Mediterranean University, Famagusta, North Cyprus
}

\author{
${ }^{*}$ Corresponding author: \\ Dlawar M. Hadi, Department \\ of Accounting, College of \\ Business, Komar University \\ of Science and Technology, \\ Sulaymania, Kurdistan \\ Region, Iraq. \\ E-mail: dlawar.mahdi@ \\ komar.edu.iq \\ Received: 13 December 2019 \\ Accepted: 24 February 2020 \\ Published: 30 June 2020

\section{DOI} \\ 10.25156/pt.v10n1y2020.pp163-169
}

\section{A B S T R A C T}

This study aims to explore the sensitivity of hotel stock prices to national and transnational terrorist incidents that occur at the world's top five tourist destinations. Event study analysis and the generalized sign test are the estimation techniques used in this study. Overall, hotel stocks were found to react differently to terrorist activities. U.S. hotel stocks were the most affected, and French hotel stocks were the least affected by domestic terrorist attacks. However, U.K. hotel stocks were the most influenced and Thai hotel stocks were the least influenced by transnational terrorist incidents. Based on the overall findings, several diversification, hedging, and speculation strategies are proposed for mitigating the effects of these influences to financial market stakeholders and hotel managers. This study recommends further studies to be conducted including various sectors to reveal how different sectors react to terrorist activities.

Keywords: Event study, Hotel industry, Stock prices, Terrorist incidents, Tourist destinations

\section{INTRODUCTION}

In financial markets, terrorist attacks are considered as unexpected events. Immediately following such attacks, investors analyze the implications for future earnings of a firm or an industry and discount future earnings to the present value of the firm, which, in turn, determines the stock value. Thus, in line with the efficient market hypothesis, stock price movements following terrorist attacks react to the incidents as new information coming to the market.

Hotels are a prime segment of the tourism industry. Travelers are the major customers and the main source of revenue for hotels, and the hospitality industry is one of the sectors most sensitive to terror and criminal activities. As noted by Albattat and Mat Som (2013), safety and security are the most important issues that affect tourists' decisions while selecting a destination to travel. Tourists also seek to be protected from any type of hazard. Terrorist activities can damage tourist destinations' overall reputation for safety, attractiveness, and comfort. This, in turn, causes a downturn in the local travel and tourism economy, and the reduction in tourist arrivals and expenditures interrupts the continuity of business operations for the local hospitality industry. These effects consequently threaten the operations of hospitalityrelated companies at least temporarily until recovery can be undertaken. Regardless of the variety of terrorist attacks, the hospitality industry shares the same challenges as the attacked countries, though the magnitude of these effects varies across countries (Sonmez et al., 1999).

When a country faces serious terrorist attacks, tourists may change their destination to a safer one, which, in turn, lowers the prospective earnings of hotels as they receive fewer customers. This situation is reflected in stock prices as investors immediately discount their effects on the stocks' current value. In addition, hotels in the neighborhood and relevant markets may be negatively or positively affected. To test this hypothesis, this study uses a sample of listed hotels in the top five tourist destinations in the world, namely, the United States, Spain, France, Thailand, and the United Kingdom, where extreme terrorist attacks occurred. ${ }^{1}$ The findings of this study can benefit all financial market stakeholders in addition to hotel financial managers.

For more than three decades, considerable research has been conducted concerning the relationship between terrorism and tourism, for instance, in studies such as Richter and Waugh (1986) and Ryan (1993). Enders and Sandler (1991) documented the inverse causality of terrorism on the number of tourist visitors. Raza and Jawaid (2013) explored the short-term and long-term

1 The countries are ranked by tourism receipts (World Tourism Organization, 2018). 
negative impacts of terrorism on tourism. Nonetheless, Liu and Pratt (2017) noted that international tourism is resilient to terrorism and that the impact of terrorism varies across destinations with different political instabilities, income levels, and tourism intensities. Further, Bassil et al. (2017) found the evidence for the transnational effects of terrorism on tourism. The study also argued that terrorism activities cause tourists to alter their destinations in favor of safer places. Kilıçlar et al. (2018), however, argued that security forces and civilian authorities have different perspectives on terrorism prevention.

The relevant financial literature includes a considerable number of empirical studies devoted to investigating the impact of terrorist incidents on financial markets. Most of the studies, such as Arin et al. (2008) and Balcilar et al. (2018), documented a negative impact of terror on financial market return and volatility using a country's prime market index. While examining the sectorial effects of terror across industries, other studies reported that terrorist incidents negatively influence the airline industry (Kolaric and Schiereck 2016; Drakos, 2004), the insurance industry (Chesney et al., 2011), and the chemical and electricity sector (Kollias et al., 2011). Nonetheless, further studies by Berrebi and Klor (2010) and Apergis and Apergis (2016) observed that terrorist incidents increase stock returns of the defense sectorrelated companies. However, banking and the financial sector are the safest following a terrorist attack (Chen and Siems, 2004; Chesney et al., 2011).

Regarding the travel and tourism industry-related stocks, Chesney et al. (2011) explored a significant negative impact of global terrorist attacks on the FTSE All World Index. Zopiatis et al. (2018) reached the same conclusion, except for Australia, while examining the influence of 150 terrorist attacks, natural catastrophes, and war conflicts on FTSE Travel and Leisure World, FTSE Travel and Leisure Asia Pacific, FTSE Travel and Leisure Australia, FTSE Travel and Leisure America, and FTSE Travel and Leisure Europe indices. Hadi et al. (2019) reached the same conclusion while investigating the reactions of tourism, travel, and leisure firms to terrorist incidents in the world's top ten tourist destinations. Notably, no previous study examines the implications of terrorism for hotels.

As mentioned earlier, available studies in the literature examined the relationship between terrorism and the financial market or focused on limited sectors, while the hotel industry has been totally ignored. In contrast to the previous research, this study is novel in its focus on the reaction of hotels to domestic and international terrorist incidents through comprehensive analysis.

\section{DATA AND METHODOLOGY}

Since the terrorist attacks under consideration did not target a specific hotel, this study uses hotel indices for the sample countries included in this study to capture the overall reaction of the hotel industries to the terrorist incidents. However, except for the United States; a hotel index is not introduced in the financial market of the rest of the sample countries. Therefore, the hotel indices were created as the combined value-weighted hotel stock prices for six hotels for France, two hotels for Spain, three hotels for the United Kingdom, and seven hotels for Thailand. ${ }^{2}$

The national stock market index is used as a portfolio benchmark index for each sample country. The data for this study were collected from the Thomson Reuters Data Stream database [Appendix 1]. The examined terrorist attacks are the September 11, 2001, attacks in New York City; the March 11, 2004, attacks in Madrid; the November 13, 2015, attacks in Paris; the August 17, 2015, attack in Bangkok; and the July 7, 2005, attacks in London.

The event study methodology is still one of the most often used approaches to examining the impact of an event on stock returns in the relevant financial literature. In this study, the traditional market model and event study analysis introduced by Brown and Warner (1985) was used. The estimation window consisted of 250 trading days, and the event window spanned the period from 10 trading days before the attack through 10 trading days after the attack. This study also used a nonparametric generalized sign test introduced by Cowan (1992) to contrast the negative and positive abnormal returns (AR) surrounding the events to their corresponding points during a normal period. Fianlly, The Zivot and Andrews (ZA) (1992) structural break test with intercept and trend is applied using data for 250 trading days prior and after the event of the hotel indices returns to investigate whether the incidents caused a structural break shift.

\section{EMPIRICAL RESULTS}

\section{Descriptive Analysis}

As shown in Table 1 , the mean of $(0,+10)$ AR is negative or more negative than $(-10,-1)$ AR for all hotel indices in response to domestic terrorist attacks, which implies the inverse effect of terror on the hotel industry. The only exception is the Thai hotels, where the standard deviation of $(0,+10)$ AR is considerably higher than $(-10,-1)$ AR in the case of the United States, Spain, and Thailand, reflecting

2 The list of the sample hotels included in this study are presented in the appendix 1. 
Table 1: Descriptive statistics of AR and structural break test for hotel indices in response to domestic attacks

\begin{tabular}{|c|c|c|c|c|}
\hline \begin{tabular}{|l|}
$\begin{array}{l}\text { Hotel } \\
\text { indices }\end{array}$ \\
\end{tabular} & & $\operatorname{AR}(-10,-1)$ & AR $(0,+10)$ & $\mathrm{ZA}_{\mathrm{i}, \mathrm{t}}$ Break \\
\hline \multicolumn{5}{|c|}{ United States } \\
\hline & Mean & -0.0107 & -0.0239 & 17.09 .2001 \\
\hline & Median & -0.0106 & -0.0051 & $(-23.85)^{*}$ \\
\hline & S.D. & 0.0129 & 0.0765 & \\
\hline & Kurtosis & 0.0447 & 6.5268 & \\
\hline & Skewness & -0.650 & -2.326 & \\
\hline \multicolumn{5}{|l|}{ Spain } \\
\hline & Mean & 0.0030 & -0.0069 & 22.05 .2003 \\
\hline & Median & 0.0060 & -0.0103 & $(-23.01)^{*}$ \\
\hline & S.D. & 0.0082 & 0.0134 & \\
\hline & Kurtosis & -1.3916 & -1.4992 & \\
\hline & Skewness & -0.3557 & -0.0719 & \\
\hline \multicolumn{5}{|l|}{ France } \\
\hline & Mean & 0.0147 & -0.0041 & 04.04 .2016 \\
\hline & Median & 0.0027 & -0.0007 & $(-24.18)^{\star}$ \\
\hline & S.D. & 0.0396 & 0.0217 & \\
\hline & Kurtosis & 9.9391 & 8.6864 & \\
\hline & Skewness & 3.1492 & -2.7783 & \\
\hline \multicolumn{5}{|l|}{ Thailand } \\
\hline & Mean & -0.0026 & 0.0002 & 24.02.2015 \\
\hline & Median & -0.0015 & 0.0053 & $(-25.72)^{*}$ \\
\hline & S.D. & 0.0050 & 0.0523 & \\
\hline & Kurtosis & 0.0892 & 0.7348 & \\
\hline & Skewness & -0.8456 & -1.0527 & \\
\hline \multicolumn{5}{|c|}{ United Kingdom } \\
\hline & Mean & 0.0007 & -0.0014 & 26.05.2006 \\
\hline & Median & -0.0021 & -0.0006 & $(-27.06)^{\star}$ \\
\hline & S.D. & 0.0115 & 0.0102 & \\
\hline & Kurtosis & 0.6759 & -0.8266 & \\
\hline & Skewness & 0.6898 & -0.2360 & \\
\hline
\end{tabular}

ZA is Zivot and Andrews' structural break test with intercept and trend. The values in parentheses are $t$-statistics. ${ }^{*}$ reflects the stationary of the series at $1 \%$ significant level, AR: Abnormal returns

the impact of the incidents on the volatility of hotel stocks. For $(0,+10) A R$, with no exception, the mean is more negative than the median as the distribution is negatively skewed. Regarding the kurtosis, the distribution of AR $(0$, $+10)$ shows high positive values for the U.S. and French hotels, that is, the dataset has heavier tails than a normal distribution as the result of extreme values. However, other countries' hotels exhibit a platykurtic distribution, which is flatter than a normal distribution. Finally, in terms of the breakpoint test, the terrorist incidents cause a break in the returns of hotel stocks only in the United States.

\section{Event Study Analysis}

Table 2 shows both AR and cumulative AR (CAR) of the hotel indices following the domestic and international terrorist incidents in the world's top five tourist destinations. The ARs are exhibited graphically in Figure 1 as well. Indeed, notably different reactions of hotel indices to terror activities can be observed.
Not surprisingly, the September 11 attacks had a statistically significant and strong negative impact on U.S., Spanish, French, and U.K. hotel stock returns. Internationally, the U.K. hotels were the most affected by the attacks, while French hotel stocks were less responsive to the incidents. This outcome is quite intuitive. The attacks caused huge fatalities and damage to property, precipitating the deterioration of the tourism market. This further implies that in response to terrorist attacks the behavior of hotel stocks in Europe and in the United States are interrelated. Another explanation is that the attacks were alerting for an extension to Europe. However, Thai hotels were not significantly influenced by the attacks, possibly because of the geographical location of Thailand in Far East Asia. Further, the UK hotels were the most affected by the September 11 attacks. An explanation can be because of the political integration between The U.K. and the U.S. in their continuous wars against terror and the attacks absorbed by the investors to extend to the U.K. as well.

The impact of the Madrid attacks was limited to Spanish hotels. CAR $(0,+1)$ and $(0,+5)$ are $4.68 \%$ and $5.25 \%$, respectively. As the attacks were not suicidal and were executed through bombing, further attacks might have been anticipated until security forces eliminated the threat. The event was perceived as fundamentally negative news that inversely impacted investor behavior. Interestingly, French hotel stocks were not significantly influenced by the Paris attacks. The U.S. and Spanish hotels, however, were inversely influenced by the Paris attacks, which illustrate the cross-border effect of terrorism on the hotel industry. An explanation for this is that investors typically perceive French hotels as safe in a period of chaos. In addition, terrorist incidents seem to be tentative news and the French hotel stock prices are driven by substantial news rather than tentative news.

Although the Bangkok, Thailand, attacks specifically targeted tourists in a touristic area, the attack had a short negative effect - only Thai hotels were affected, only on the attack day which caused a decrease in AR by $10.23 \%$. However, this effect was eliminated just after the attacks and became positive but not statistically significant over CAR $(0,+10)$. The reason could be the resilience of the tourism market in Thailand, as the stock price adjusted to the magnitude and length of the threat. This also reflects the strength of the hotel industry in Thailand, which is not affected by temporary events.

Finally, the London attacks had no inverse influence on U.K. hotels, or on the other four of the top five tourist 
Table 2: AR and CAR of hotel indices following terrorist incidents

\begin{tabular}{|c|c|c|c|c|c|}
\hline Incidents & Hotel Indices & AR & $\operatorname{CAR}(0,+1)$ & $\operatorname{CAR}(0,+5)$ & $\operatorname{CAR}(0,+10)$ \\
\hline \multicolumn{6}{|l|}{ United States } \\
\hline \multirow{5}{*}{$\begin{array}{l}\text { The September } 11 \text {, } \\
\text { 2001, attacks }\end{array}$} & United States & $-22.35 \% *$ & $-27.59 \% *$ & $-29.47 \% *$ & $-26.37 \%^{*}$ \\
\hline & Spain & $-15.39 \% *$ & $-22.87 \% \%^{*}$ & $-27.85 \% *$ & $-26.00 \%{ }^{*}$ \\
\hline & France & $-1.68 \%$ & $-6.48 \% *$ & $-10.92 \%{ }^{*}$ & $-11.25 \%$ ** \\
\hline & Thailand & $0.49 \%$ & $0.54 \%$ & $-0.75 \%$ & $-4.04 \%$ \\
\hline & United Kingdom & $-10.29 \% *$ & $-18.28 \% *$ & $-37.44 \% *$ & $-39.10 \% *$ \\
\hline \multicolumn{6}{|l|}{ Spain } \\
\hline \multirow{5}{*}{$\begin{array}{l}\text { The March 11, 2004, } \\
\text { attacks in Madrid }\end{array}$} & United States & $-0.84 \%$ & $-1.38 \%$ & $-2.42 \%$ & $4.51 \%$ \\
\hline & Spain & $-2.06 \%$ & $-4.68 \%$ ** & $-5.25 \%$ ** & $-7.61 \%$ \\
\hline & France & $-0.10 \%$ & $-0.83 \%$ & $-0.83 \%$ & $-0.70 \%$ \\
\hline & Thailand & $0.01 \%$ & $0.57 \%$ & $-3.04 \%$ & $-3.48 \%$ \\
\hline & United Kingdom & $1.10 \%$ & $2.47 \%$ & $2.71 \%$ & $4.11 \%$ \\
\hline \multicolumn{6}{|l|}{ France } \\
\hline \multirow{5}{*}{$\begin{array}{l}\text { The November } 13 \text {, } \\
2015 \text {, attacks in Paris }\end{array}$} & United States & $-2.36 \%$ ** & $-3.51 \% *$ & $-4.11 \%$ *** & $-5.07 \%$ *** \\
\hline & Spain & $-2.49 \%$ ** & $-4.09 \%$ ** & $-2.55 \%$ ** & $-7.43 \%$ ** \\
\hline & France & $1.54 \%$ & $1.70 \%$ & $0.42 \%$ & $1.65 \%$ \\
\hline & Thailand & $-0.28 \%$ & $-1.90 \%$ & $-4.21 \%$ & $-4.21 \%$ \\
\hline & United Kingdom & $0.08 \%$ & $-0.72 \%$ & $-0.37 \%$ & $-1.75 \%$ \\
\hline \multicolumn{6}{|l|}{ Thailand } \\
\hline \multirow{5}{*}{$\begin{array}{l}\text { The August } 17,2015 \text {, } \\
\text { attack in Bangkok }\end{array}$} & United States & $-0.47 \%$ & $0.15 \%$ & $0.21 \%$ *** & $3.76 \%$ \\
\hline & Spain & $1.53 \%$ & $2.50 \%$ & $-0.24 \%$ & $0.93 \%$ \\
\hline & France & $-0.36 \%$ & $-0.02 \%$ & $0.71 \%$ & $2.87 \%$ \\
\hline & Thailand & $-10.23 \% *$ & $-4.83 \%$ & $-0.09 \%$ & $0.24 \%$ \\
\hline & United Kingdom & $0.29 \%$ & $0.90 \%$ & $1.08 \%$ & $4.68 \%$ \\
\hline \multicolumn{6}{|l|}{ United Kingdom } \\
\hline \multirow{5}{*}{$\begin{array}{l}\text { The July } 7,2005 \text {, } \\
\text { attacks in London }\end{array}$} & United States & $-0.57 \%$ & $-1.06 \%$ & $0.31 \%$ & $-2.90 \%$ \\
\hline & Spain & $-0.47 \%$ & $1.84 \%$ & $5.04 \%$ ** & $5.08 \%$ *** \\
\hline & France & $-0.25 \%$ & $0.53 \%$ & $0.75 \%$ & $0.38 \%$ \\
\hline & Thailand & $0.75 \%$ & $0.73 \%$ & $-0.10 \%$ & $0.71 \%$ \\
\hline & United Kingdom & $-1.82 \%$ & $-1.41 \%$ & $-0.44 \%$ & $-2.90 \%$ \\
\hline
\end{tabular}

${ }^{*},{ }^{* *}$, and ${ }^{* * *}$ represent $1 \%, 5 \%$, and $10 \%$ level of significance, respectively, AR: Abnormal returns, CAR: Cumulative AR.

destinations in the world. In contrast, the Spanish hotels' stock returns increased by more than $5 \%$. This implies that investors consider the Spanish tourism market an alternative to the U.K. market were Spanish hotels' performance anticipated to increase as potential tourists can easily choose a safer destination.

In terms of average $A R(A A R)$ and cumulative average AR (CAAR), overall influences of the terrorist incidents on the cross-section hotel indices of the world's top five tourist destinations are shown in Table 3. Although AAR on the event day is negative, it is not statistically significant. The findings of the generalized sign test support the results of the event study analysis that a great proportion of AR $(83.3 \%)$ were found to be negative following the incidents. CAAR over the span of 1,5 , and 10 days after the attacks are negative and statistically significant, as the outcome of both AAR and CAAR shows a downward trend [Figure 2], implying that the global hotel industry is indeed influenced by terror activities. The overall findings document an extreme
Table 3: AAR and CAAR of hotel indices in response to domestic terrorist incidents

\begin{tabular}{lcc}
\hline Returns & Coefficient & Generalized sign tests 0>\% \\
\hline AAR & $-5.80 \%$ & $66.7 \%$ \\
& $(-8.89)^{\star}$ & {$[0.77]$} \\
CAAR $(0,+1)$ & $-6.39 \%$ & $83.33 \%$ \\
& $(-6.93)^{\star}$ & {$[3.85]^{* *}$} \\
CAAR $(0,+5)$ & $-6.56 \%$ & $83.33 \%$ \\
& $(-4.10)^{\star *}$ & {$[3.85]^{\star *}$} \\
CAAR $(0,+10)$ & $-7.21 \%$ & $83.33 \%$ \\
& $(-3.33)^{\star *}$ & {$[3.85]^{* *}$} \\
\hline
\end{tabular}

*and ** represent the significant level at $1 \%$ and $5 \%$, respectively. The values between parentheses are t-statistics, and values in brackets are generalized Z statistics. AR: Abnormal returns, CAR: Cumulative AR, CAAR: Cumulative average abnormal returns

converse impact of domestic terrorist incidents on the hotel industry. This finding is quite intuitive as hotels constitute the prime segment of the travel and leisure sector, which is one of the sectors most vulnerable to terror activities (Sonmez et al., 1999). 


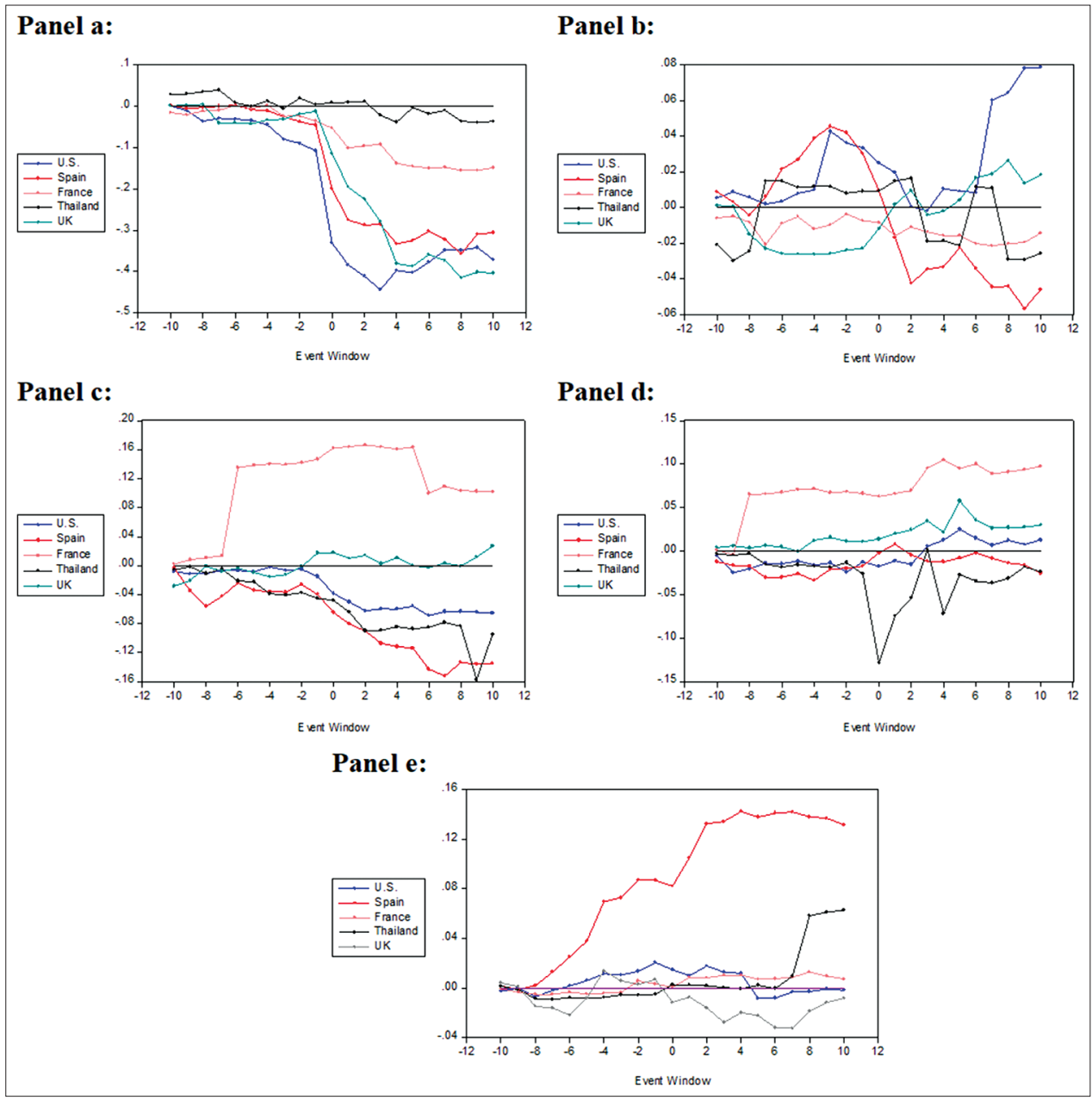

Figure 1: Domestic and transnational effects of terror on the hotel stocks. Panel a: Domestic and transnational effects of September 11 attacks on the hotel indices. Panel b: Domestic and transnational effects of Madrid bombing attacks on the hotel indices. Panel c: Domestic and transnational effects of Paris attacks on the hotel indices. Panel d: Domestic and transnational effects of Bangkok terrorist incident on the hotel indices. Panel e: Domestic and transnational effects of London terrorist incident on the hotel indices

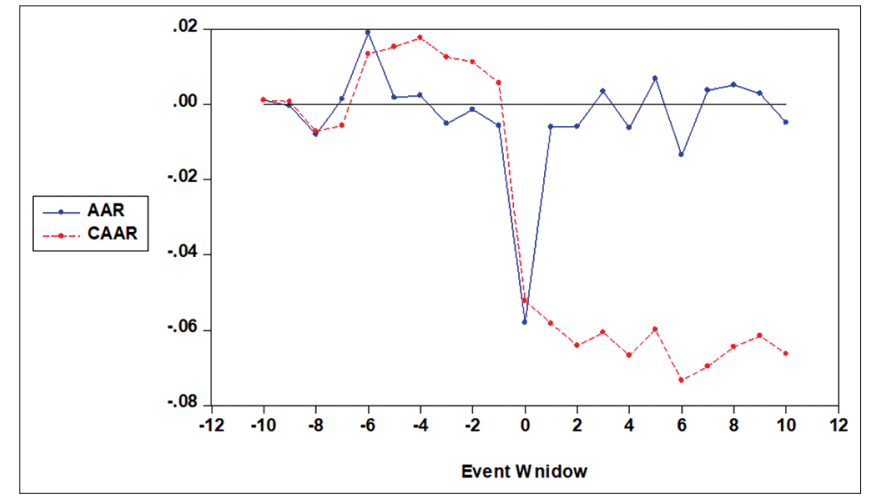

Figure 2: Average abnormal returns (AR) and cumulative average AR

\section{CONCLUSION}

This paper examines the potential influences of terrorism on hotel performance in the world's top five tourist destinations - the United States, Spain, France, Thailand, and the United Kingdom. In particular, the reaction of hotel stocks to national and transnational terror activities is examined. The three empirical findings document different reactions to domestic and international terrorist incidents: First, domestic terror inversely affected hotel performance (e.g., negative response of the U.S., Spanish, and Thai hotels to national attacks). Second, terror has transnational effects on hotel performance (e.g., the Spanish, French, and U.K. hotels inversely reacted to the September 11 attacks, and the U.S. and Spanish hotels conversely responded to the Paris attacks). Third, the Spanish market is a substitute tourism market for the United Kingdom (e.g., Spanish hotels performance reacted favorably following the London attacks). Further findings of CAAR and the generalized sign test explore the negative impact of terror on hotel performance. These findings are consistent with the efficient market hypothesis. Based on the findings of this study, it is recommended that the hotel managers and financial market investors should be very cautious in their decisions during the turbulence period. The stock prices 
are volatile and the reactions of hotel stocks to terror can vary domestically, internationally, or based on the attacks and markets. In addition to the theoretical contribution to sustainable tourism literature, the findings also propose several diversifications, hedging, and benefits strategies to domestic and international investors and portfolio managers. These findings are valuable for hotel managers as well.

\section{REFERENCES}

Albattat, A. R. and A. P. M. Som. 2013. Emergency preparedness for disasters and crises in the hotel industry. Sage Open. 3(3): 5604.

Apergis, E. and N. Apergis. 2016. The 11/13 Paris terrorist attacks and stock prices: The case of the international defense industry. Financ. Res. Lett. 17: 186-192.

Arin, K. P., D. Ciferri and N. Spagnolo. 2008. The price of terror: The effects of terrorism on stock market returns and volatility. Econ. Lett. 101(3): 164-167.

Balcilar, M., R. Gupta, C. Pierdzioch and M. E. Wohar. 2018. Terror attacks and stock-market fluctuations: Evidence based on a nonparametric causality-in-quantiles test for the $\mathrm{G} 7$ countries. Eur. J. Financ. 24(4): 333-346.

Bassil, C., A. S. Saleh and S. Anwar. 2017. Terrorism and tourism demand: A case study of Lebanon, Turkey and Israel. Curr. Issues Tour. 22(1): 50-70.

Berrebi, C. and E. F. Klor. 2010. The impact of terrorism on the defence industry. Economica. 77(307): 518-543.

Brown, S. J. and J. B. Warner. 1985. Using daily stock returns: The case of event studies. J. Financ. Econ. 14(1): 3-31.

Chen, A. H. and T. F. Siems. 2004. The effects of terrorism on global capital markets. Eur. J. Pol. Econ. 20(2): 349-366.

Chesney, M., G. Reshetar and M. Karaman. 2011. The impact of terrorism on financial markets: An empirical study. J. Bank. Financ. 35(2): 253-267.
Cowan, A. R. 1992. Nonparametric event study tests. Rev. Quant. Financ. Account. 2(4): 343-358.

Drakos, K. 2004. Terrorism-induced structural shifts in financial risk: Airline stocks in the aftermath of the September $11^{\text {th }}$ terror attacks. Eur. J. Pol. Econ. 20(2): 435-446.

Enders, W. and T. Sandler. 1991. Causality between transnational terrorism and tourism: The case of Spain. Stud. Confl. Terror. 14(1): 49-58.

Hadi, D. M., S. Katircioglu. and C. Adaoglu. 2019. The vulnerability of tourism firms' stocks to the terrorist incidents. Curr. Issues Tour. 23: 1-15.

Kılıçlar, A., A. Uşaklı and A. Tayfun. 2018. Terrorism prevention in tourism destinations: Security forces vs. civil authority perspectives. J. Destin. Mark. Manage. 8: 232-246.

Kolaric, S. and D. Schiereck. 2016. Are stock markets efficient in the face of fear? Evidence from the terrorist attacks in Paris and Brussels. Financ. Res. Lett. 18: 306-310.

Kollias, C., S. Papadamou and A. Stagiannis. 2011. Terrorism and capital markets: The effects of the Madrid and London bomb attacks. Int. Rev. Econ. Financ. 20(4): 532-541.

Liu, A. and S. Pratt. 2017. Tourism's vulnerability and resilience to terrorism. Tour. Manage. 60: 404-417.

Raza, S. A. and S. T. Jawaid. 2013. Terrorism and tourism: A conjunction and ramification in Pakistan. Econ. Mod. 33: 65-70.

Richter, L. K. and W. L. Waugh. 1986. Terrorism and tourism as logical companions. Tour. Manage. 7(4): 230-238.

Ryan, C. 1993. Crime, violence, terrorism and tourism: An accidental or intrinsic relationship? Tour. Manage. 14(3): 173-183.

Sonmez, S. F., Y. Apostolopoulos and P. Tarlow. 1999. Tourism in crisis: Managing the effects of terrorism. J. Trav. Res. 38(1): 13-18.

World Tourism Organization. 2018. Available from: http://www2. unwto.org. [Last accessed on 2018 Dec 03].

Zivot, E. and D. W. K. Andrews. 1992. Further evidence of the great crush, the oil price shock and the unit root hypothesis. J. Bus. Econ. Stat. 10: 251-70.

Zopiatis, A., C. S. Savva, N. Lambertides and M. McAleer. 2018. Tourism stocks in times of crisis: An econometric investigation of unexpected nonmacroeconomic factors. J. Trav. Res. 58: 459-479. 


\section{APPENDIX 1}

\section{Sample hotels}

UK

1

2 HYDRO HOTELS (EASTBO'NE)

3 MILLENNIUM AND CPTH.HTLS.

France

1 SOC IMMOBILIERE ET EXPLOIT HOTEL MAJESTI

2 HOTELIM LIMITED DATA

3 LES HOTELS BAVEREZ

4 LES HOTELS DE PARIS

5 HOTEL IMMOB NICE

6 ACCOR

Spain

1

2

MELIA HOTELS INTL.

NH HOTEL GR

USA

1

Dow Jones Hotels Index

Thailand

1 ASIA HOTEL

2 ROYAL ORCHID HTL. (THAI.)

3 CENTRAL PLAZA HOTEL

4 SHANGRI-LA HOTEL

$5 \quad$ OHTL

6 MANDARIN HOTEL

7 LAGUNA RESORTS \& HOTELS 